\title{
Contraception and Double Effect
}

\author{
Ezio Di Nucci \\ (Universität Duisburg-Essen, ezio.dinucci@uni-due.de)
}

\begin{abstract}
I argue that opposition to contraception is not made any less implausible by the application of the Doctrine of Double Effect, as for example in the case of the recent argument according to which double effect can be deployed to make the prescription of Combined Oral Contraceptives compatible with Catholic teachings.
\end{abstract}

I argue that opposition to contraception is not made any less implausible by the application of the Doctrine of Double Effect, as for example in the case of the recent argument that double effect can be deployed to make the prescription of Combined Oral Contraceptives (COC) compatible with Catholic teachings (Casey \& Salzman, forthcoming).

The dialectic of this debate is common to many applications of double effect: a deontological rule which is - either in itself or because of its generality - implausible should be supposedly made less implausible by showing that - because of the Doctrine of Double Effect - the rule does not actually forbid as much as it was thought to forbid. Indeed, this is also historically the dialectic of Aquinas' original introduction of praeter intentionem (which was later to be formalized into the Doctrine of Double Effect) to make the Commandment against killing less implausible: simplifying Aquinas' point, the idea would be that if we recognise that the Commandment is against intentional killing and see that someone who kills in self-defence does not necessarily intend to kill (and also - would add the contemporary philosopher of 
action - accept that intentional A-ing requires an intention to A), then we can conclude that the Commandment against killing does not actually necessarily forbid killing in self-defence.

Mutatis mutandis, those who consider contraception morally problematic try to argue that, by application of the Doctrine of Double Effect, one can show the position to have less implausible consequences than it could have otherwise been thought to have: so that for example $\mathrm{COC}$ can be prescribed as long as those prescribing them do not intend their contraceptive effects but only their therapeutic effects. The basic idea is that if one prescribes $\mathrm{COC}$ without intending $\mathrm{COC}$ to have contraceptive effects one does not violate the rule forbidding contraception because that rule - just as the rule against killing from which it is by the way directly derived - is actually a rule against a special sense of intentional contraception, one which is supposedly not fulfilled by prescribing COC without intending their contraceptive effects.

The stakes - this should be clear by now - could not be higher: the issue isn't just COC; the issue is more generally and more importantly the morality of killing and whether the Doctrine of Double Effect can do anything to make a general principle against killing less implausible. Accordingly, it won't do to just analyse COC and double effect: we must not lose sight of the general role of double effect within the morality of killing.

For the sake of argument, suppose contraception were immoral (which it is not): could it be morally acceptable to prescribe a drug which is known to have contraceptive effects, which are themselves, we are supposing, immoral? A few irrelevant options must be ruled out here: 
(i) the doctor may not know that the drug she is prescribing has contraceptive effects; that may indeed make a moral difference but is beside the point at stake here;

(ii) the patient may be ignorant about the contraceptive effects so that we may even be able to argue that when the patient takes the drug that is not a genuine case of contraception so that it is not ruled out by the supposed prohibition against contraception; whatever the merits of this distinction between intensional and extensional contraception, this is also beside the point here because we are talking about the morality of the doctor prescribing the drug;

(iii) any combination of (i) and (ii) will also be beside the point for the reasons just given.

Let us now return to our question: if $X$ is immoral, may a doctor prescribe a drug which the doctor knows to have $X$ as one of its effects? Well, that does depend - you may answer - on which other effects the drug has, as its other effects may outweigh $\mathrm{X}$. This is a fair answer, but obviously not an answer which is available within absolutist deontological approaches: if $\mathrm{X}$ is immoral and thereby morally prohibited within our deontological system, then no other effect can trump that. That is both the big issue with plausibility which deontological approaches tend to have and the point at which some deontological approaches tend to appeal to the Doctrine of Double Effect - and one may legitimately suspect a connection there.

The suggested application of double effect is supposed to work as follows: if $X$ is immoral, a doctor may prescribe a drug which she knows to have $X$ as one of its effects as long as the doctor does not intend the drug to have effect $X$ (and other conditions apply, such as 
traditionally proportionality ${ }^{1}$ ). To put it simply, the difference between prescribing the drug while knowing that it has effect $X$ and prescribing the drug with the intention to produce effect $X$ is supposed to be morally relevant; indeed, this difference is not supposed to be just morally relevant but rather morally decisive to the extent that the former but not the latter is supposedly morally permissible even given a prohibition against $X$.

The crucial remaining question is why this distinction between (merely) knowing and intending should be crucial when it comes to the moral permissibility of prescribing the drug or any other action. And importantly the answer cannot appeal to whatever other positive effects the drug may have, because those other positive effects are there whether or not the agent intends $\mathrm{X}$ so that these other effects are irrelevant to the question under discussion. $\mathrm{A}$ traditional answer is that what is paramount is aiming at the good and that we can aim at the good as long as we avoid immoral intentions, so that sometimes knowingly bringing about some bad may be compatible with aiming at the good as long as we do not intend the relevant bad.

Whatever one makes of this point, it is apparent that even accepting it constitutes the beginning of the end for absolutist deontology. If the point of absolutist deontology is that a prohibition against $\mathrm{X}$ is absolute and we now say that as long as we pursue the good we can, under certain circumstances, knowingly bring $X$ about, then $X^{\prime}$ s prohibition is no longer absolute. And this is the crucial point about deploying double effect which goes beyond the present debate on contraception: the use of double effect is made necessary by the absolute

\footnotetext{
${ }^{1}$ There are a lot of issues related to the Doctrine of Double Effect which I cannot cover here in enough detail, but I have written on double effect extensively elsewhere, see Di Nucci 2008, Di Nucci 2012, Di Nucci 2013a, Di Nucci 2013b, Di Nucci 2013c, Di Nucci 2013d, Di Nucci 2014, Di Nucci forthcoming a, and Di Nucci forthcoming b.
} 
nature of the prohibitions in question; but at the same time the use of double effect undermines the absolute nature of the prohibitions in question. If the prohibitions weren't absolute to begin with, there would not have been any need for double effect; but once we do apply double effect, then the prohibitions are no longer absolute because we are delineating at least one way in which bringing about the supposedly absolute bad is actually legitimate.

In short, appeals to double effect undermine the absolute nature of the prohibitions that those appeals are meant to rescue from the challenge of implausibility, whether we are talking about the specific issue of contraception or the more general issue of killing or another moral problem. But there are other problems with double effect: think of the consequences - for the general prohibition against contraception - of accepting that a doctor may permissibly prescribe a drug which she knows to have contraceptive effects as long as she does not intend those effects. Anyone could then use contraceptives with similar arguments: against STDs, for example. If a doctor can claim not to intend the contraceptive effects as long as she prescribes the drug because of its other beneficial effects, then surely anybody can claim not to intend the contraceptive effects as long as they are (also) interested in the effects some contraceptives have against STDs, for example. This is a well known problem for double effect: as soon as it has been deployed to allow one particular case, it lets in all sorts of cases that it wasn't supposed to allow, so that the Doctrine ends up being useless as a distinctive principle which should allow some cases but prohibit others.

Summing up, here I have shown that appealing to the Doctrine of Double Effect does not make a prohibition against contraception any less implausible, because double effect fails to 
justify the prescription of $\mathrm{COC}$ while at the same time upholding a general prohibition against contraception. Now, one may at this stage point to the dialectic nature of my argument and suggest that my argument may just as well be used to argue that no form of contraception is permissible; as I said, I am rather inclined towards the opposite conclusion: an absolute prohibition against contraception is so implausible that even those supporting such prohibition try to appeal to double effect to allow for some exceptions. Given the implausibility of the absolute prohibition and the failure to allow for exceptions, the obvious alternative is to drop the prohibition altogether. 
References

Casey M \& Salzman T (forthcoming). Therapeutic, Prophylactic, Untoward and Contraceptive Effects of Combined Oral Contraceptives. Catholic Teaching, Natural Law and the Principle of Double Effect when Deciding to Prescribe and Use. American Journal of Bioethics.

Di Nucci E (2008). Mind out of Action. Saarbrücken: VDM Verlag.

Di Nucci E (2012). Double Effect and Assisted Dying. British Medical Journal (letter, 7.2.2012). Di Nucci E (2013a). Double Effect and Terror Bombing. In Miguel Hoeltje, Thomas Spitzley \& Wolfgang Spohn (eds.), Was dürfen wir glauben? Was sollen wir tun? Sektionsbeiträge des achten internationalen Kongresses der Gesellschaft für Analytische Philosophie e.V. DuEPublico.

Di Nucci E (2013b). Embryo Loss and Double Effect. Journal of Medical Ethics 39 (8): 537-540.

Di Nucci E (2013c). Self-Sacrifice and the Trolley Problem. Philosophical Psychology 26 (5): 662-672.

Di Nucci E (2013d). Mindlessness. Newcastle-upon-Tyne: Cambridge Scholars Publishing.

Di Nucci E (2014). Ethics Without Intention. London: Bloomsbury.

Di Nucci E (forthcoming a). Aristotle and Double Effect. Journal of Ancient Philosophy.

Di Nucci E (forthcoming b). Trolleys and Double Effect in Experimental Ethics. In Christoph Lütge, Hannes Rusch \& Matthias Uhl (eds.), Experimental Ethics. Palgrave Macmillan. 